\title{
THE COMBINATION OF EXERCISE AND ASCORBIC ACID DECREASE BLOOD GLUCOSE LEVEL AND TEND TO AMELIORATE PANCREATIC ISLETS AREA ON HIGH CARBOHYDRATE DIET RATS
}

\author{
LILIK HERAWATI ${ }^{1,2 *}$, LINA LUKITASARI ${ }^{3}$, RIMBUN RIMBUN ${ }^{4}$, BAMBANG PURWANTO $^{1,2}$, GADIS MEINAR SARI ${ }^{1}$
}

${ }^{1}$ Departement of Physiology, Faculty of Medicine, Universitas Airlangga, Surabaya, Indonesia. ${ }^{2}$ Sport Clinic, Faculty of Medicine, Universitas Airlangga and Dr. Soetomo Hospital, Indonesia. ${ }^{3}$ Departement of Biochemistry, Faculty of Medicine, Universitas Airlangga, Surabaya.

${ }^{4}$ Departement of Anatomy and Histology, Faculty of Medicine, Universitas Airlangga, Surabaya. Email: lilik_heraw@fk.unair.ac.id

Received: 03 July 2018, Revised: 18 July 2018, Accepted: 22 November 2018

ABSTRACT

Objective: This study is conducted to determine the protective effects of physical exercise and ascorbic acid on increasing blood glucose (BG) levels and islet pancreatic area in high-carbohydrate $(\mathrm{HC})$ diet rats.

Methods: A total of 20 rats were divided into four groups: Control group which was a HC and treatment groups which were HC plus exercise (HCEx), HC plus ascorbic acid (HCAs), and HCEx and ascorbic acid (HCExAs). The duration of treatment was 9 weeks. Swimming to exercise held 6 times a week and ascorbic acid dose was $9 \mathrm{mg}$.

Results: It showed that the smallest body weight was HCEx group. BG difference (before and after treatment = BG diff) had a significant difference $(p=0.021)$ among groups, and the lowest level of BG diff was HCEx group. HCAs had the biggest BG diff. However, there was no significantly difference among groups on islet pancreatic area, but $\mathrm{HC}$ group had the largest area.

Conclusion: This study suggests that a combination of exercise and ascorbic acid on HC diet subject may regulate BG level compared to the exercise or ascorbic acid alone. However, they do not influence pancreatic islet area.

Keywords: High-carbohydrate diet, Exercise, Ascorbic acid, Pancreatic islets.

(C) 2019 The Authors. Published by Innovare Academic Sciences PvtLtd. This is an open access article under the CC BY license (http://creativecommons. org/licenses/by/4. 0/) DOI: http://dx.doi.org/10.22159/ijap.2019.v11s3.M1019

\section{INTRODUCTION}

Prolong increasing calories can induce obesity and metabolic disease such as diabetes. It was known that there was an association in increasing $150 \mathrm{kcal} /$ person/day in sugar with rising diabetes prevalence by $1.1 \%$ [1]. The prediction of diabetes prevalence in 2035 is 592 millions [2].

Establish prevention to diminish calories excess is physical exercise. The suggestion exercise for health maintenance is aerobic exercise [3]. Exercise can stimulate independent insulin-glucose uptake by cells and may provide a protective effect for beta cells. However, it also reveals that exercise can stimulate free radical production. In condition, there is no balance with internal antioxidant, and it can lead to pathologic process. Imbalance of free radicals and antioxidant is one of the several factors which may trigger the destruction of beta-cells of pancreatic islets [4].

Free radicals need to be neutralized with antioxidants. In China, carotene and ascorbic acid intake had reciprocal correlation with deaths from all causes in middle-aged or elderly people [5]. It also identified that highdose ascorbic acid and tocopherol consumption caused higher trend in blood glucose (BG) level on dive athletes [6]. However, the effect of exercise and ascorbic acid on pancreatic islets on high carbohydrate (HC) diet subjects is nor clearly yet. Therefore, this study is conducted to explore it.

\section{METHODS}

The research was pre-post control group experimental design, which conducted at Animal Model Laboratory of the Department of Biochemistry and Histology Laboratory of the Department of Anatomy and Histology, Faculty of Medicine, Universitas Airlangga, Surabaya, Indonesia. The study was approved by the Unit of Research and Community Service, Faculty of Medicine, Universitas Airlangga, Surabaya, Indonesia.
Health adult male Wistar rats (Rattus norvegicus), weighing 110-145 g, were acclimatized for 1 week. The sample size was five rats for each group, and the number of study groups was four groups. The group that consisted of a HC diet group as control group was given standard diet plus sugar solution, HC plus exercise (HCEx) group was given treatment as HCEx, HC plus ascorbic acid (HCA) group was given treatment as HCA solution, and HCEx and ascorbic acid group (HCExAS) were given treatment as HCEx and also ascorbic acid.

Rats were doing swimming exercise for $30 \mathrm{~min}, 6$ times a week, at about $10 \mathrm{am}-11.30 \mathrm{am}$, in $28-30^{\circ} \mathrm{C}$ water for about 9 weeks. The exercise dose was given based on the previous study (Herawati et al., 2015).

$\mathrm{HC}$ diet was $1 \mathrm{~g} / \mathrm{mL}$ white sugar solution in $2 \mathrm{~mL}$ oral gavage and $0.2 \mathrm{~g} / \mathrm{mL}$ white sugar solution as daily ad libitum drink. The oral gavage dose was converting dose from the glucose tolerance test in rats and Adeyi et al. research [7] was applied for ad libitum dose.

The ascorbic acid or Vitamin C $100 \mathrm{mg} / \mathrm{mL}, 2 \mathrm{~mL}$ in each ampule (PT Ethica), was diluted with aqua water. The dose given was $9 \mathrm{mg}$ in $2 \mathrm{~mL}$ water for each rat. The ascorbic acid dose was based on converting factor [8] from $500 \mathrm{mg}$ ascorbic acid from human dose.

Body weight (BW) in gram was measured before and after treatment. The BW variables were used for the growth observation of the rats. It consisted of BW before (BW pre), after (BW post), and the increasing difference of the before and after BW during the treatment (BW diff).

BG samples $(\mathrm{mg} / \mathrm{dL})$ were randomized BG, blood dropped from the tail, which was taken at the beginning and end of treatment. It was measured by an Accu-Chek Active glucometer. The BG level variables were $B G$ beforte treatment (BG pre), after treatment (BG post), and the 
increasing difference between BG levels after and before treatment (BG diff). The last was referred to the change of BG levels.

The increase area of islets of pancreas $\left(\mu \mathrm{m}^{2}\right)$ was calculated on Image Raster 3 software, with hematoxylin-eosin staining. Measurement of area is the average of five islets.

Normality test was performed first to determine whether the data distribution was normal or not. If the data were not normally distributed, it would be followed by Kruskal-Wallis test, and if it was normal, then it was continued with ANOVA. The significant level was set in $5 \%$

\section{RESULTS AND DISCUSSION}

\section{BW}

The BW after treatment was not significantly difference among groups $(\mathrm{p}=0.148)$ nor the increasing difference of BW $(\mathrm{p}=0.263)$ as shown in Table 1 .

The lowest BW after treatment (BW post) was $\mathrm{HC}$ diet plus exercise and also ascorbic acid group (HCExAs), and the highest of BW post was HC diet group.

This research revealed that there was no difference on BW including after treatment and the change of BW. The increase BW in this result had the same pattern alteration with the research conducted by Adeyi et al. [7].

Fig. 2 illustrates, though the HCExAs had the lowest BW post, the smallest increase of BW was the HCEx group. The largest increase was HCAs group. However, there were no significant difference among groups $(\mathrm{p} \geq 0.05)$.

Despite the insignificantly difference among groups on BW, the further exploration of the changing BW in each group was doing. It was revealed that there was noteworthy alteration in each group which found in $\mathrm{HC}$ and HCAs groups (Table 2).

It demonstrated that the significant weight gain was on HC and HCAs group. The exercised HC subject (HCEx) did not show any significant increase even though they were also given ascorbic acid (HCExAs). The exercise treatment on the HCEx and HCExAs groups disclosed a little increase on BW. According to the review article by Kanter [9], it said that physical improvement on exercise needs HC diet. However, the prior study stated that high-intensity ergocycle exercise leads to increase fat oxidation on low carbohydrate diet men compared to HC diet men [10]. The result of our study had a contrary result. The swimming exercise in this study was about moderate intensity. In HC diet subjects with moderate level of exercise, it showed the smallest raises on weight. It meant that energy metabolism was higher compared to the non-exercise subject as the recommendation for diabetes person to regulate elevated BG [11]. The weight gain on the HC subject with the ascorbic acid (with or without exercise) showed higher level compared to the exercise subject. As said by Lee et al. [12], ascorbic acid reduced mitochondria function on rats which leads to minimize oxidation of energy source.

BG

The random $B G$ before and after treatment had no significantly difference $(p=0.077$ and $p=0.074)$ (Table 3). The increasing difference of BG was significantly difference among groups $(\mathrm{p}=0.009)$.

The highest BG before treatment (BG pre) was HCExAs group, but the $B G$ of the HCExAs group unchanged after treatment. The highest of BG post was HCAs and followed by HC group which had a very little difference level compared with HCAs group.

The BG before and after treatment (BG diff) is presented in Fig. 3. The largest increase of BG diff was HCAs group. In spite of increasing BG, HCEx groups performed the decreasing of $B G$ after treatment. This result was similar with a study on diabetes people doing aerobic exercise [3].

Almost groups which set HC diet had a higher level on BG after treatment, except which performed exercise. It revealed that the exercise neutralized the effect of HC diet. However, ascorbic acid alone increased more level of BG. If ascorbic acid combined with exercise, the raised $B G$ level would be diminished.

The previous studies uncovered that high-dose antioxidant (ascorbic acid and tocopherol) in dive athletes rised blood glucose level, and

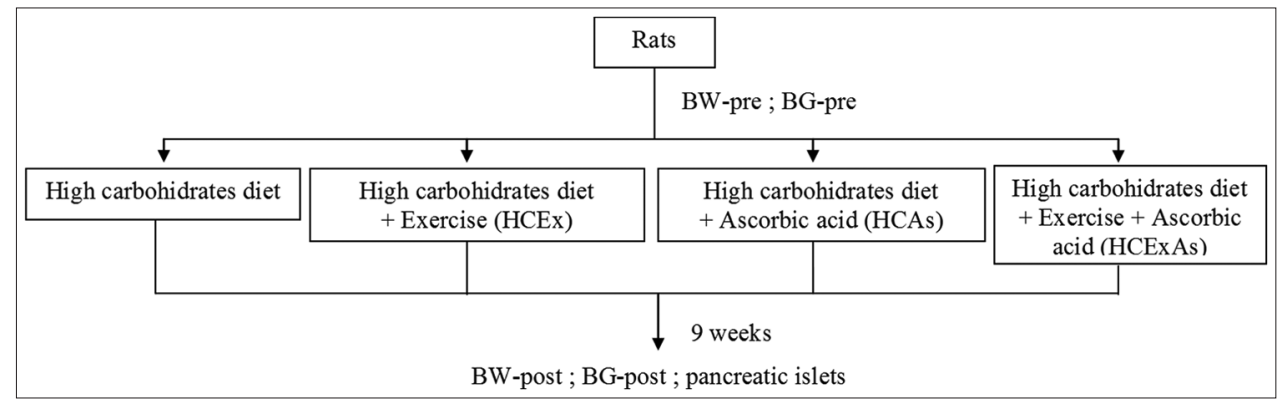

Fig. 1: Research procedure

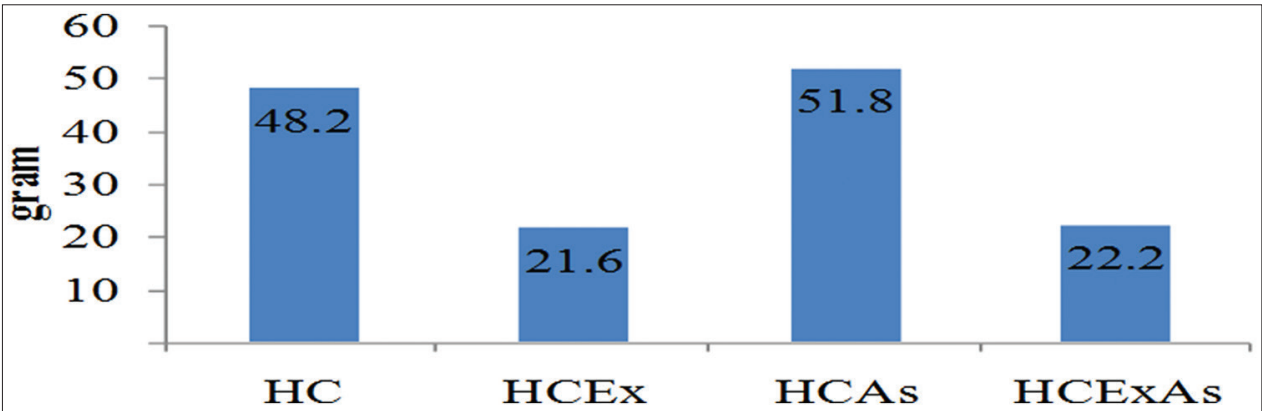

Fig. 2: The body weight difference before and after treatment. No significantly different among groups (p=0.153) 


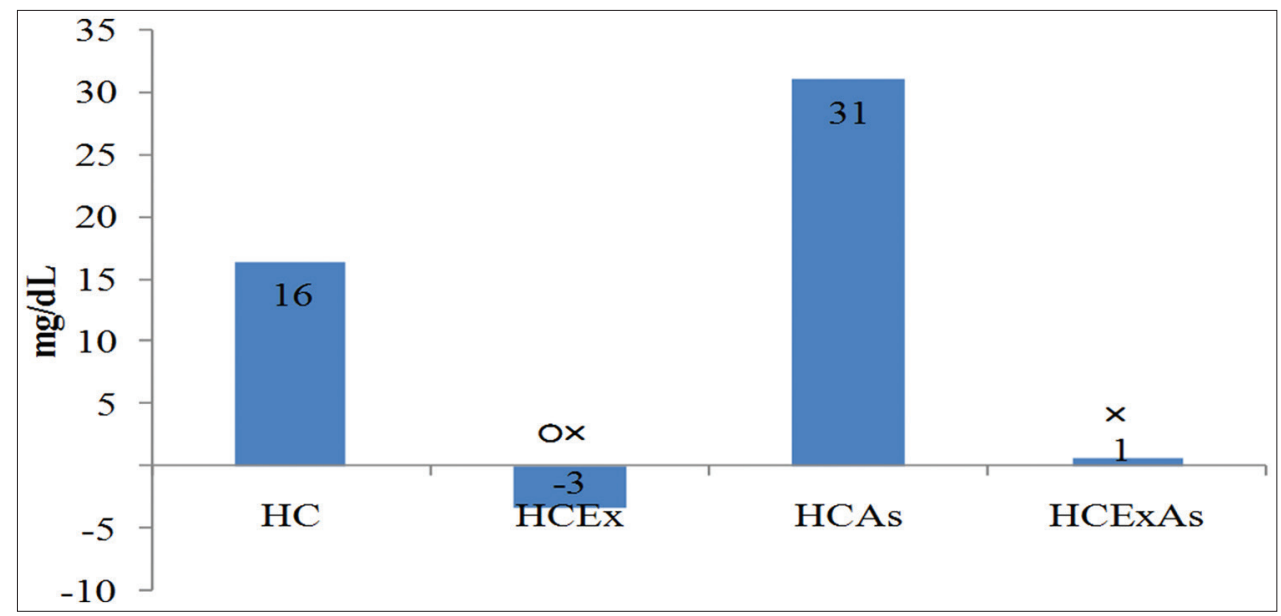

Fig. 3: The blood glucose before and after treatment (blood glucose diff). ${ }^{\circ}$ : Significantly different $(p<0.05)$ with the high-carbohydrate (HC) group. $x$ : Significantly different $(p<0.05)$ with the HC plus ascorbic acid group

Table 1: The average of BW: Before (BW pre), after (BW post), and the difference (BW diff) during the treatment

\begin{tabular}{|c|c|c|c|c|c|c|}
\hline Groups & BW pre (g) ${ }^{a}$ & $p$ value & BW post (g) & p value & $B W \operatorname{diff}(g)^{a}$ & p value \\
\hline $\mathrm{HC}$ & $128.60 \pm 7.44$ & 0.080 & $176.83 \pm 17.72$ & 0.148 & $48 \pm 16.51$ & 0.263 \\
\hline HCEx & $130.40 \pm 11.01$ & & $151.93 \pm 22.30$ & & $22 \pm 25.89$ & \\
\hline HCAs & $114.00 \pm 15.70$ & & $165.71 \pm 9.670$ & & $52 \pm 22.69$ & \\
\hline HCExAs & $115.60 \pm 10.81$ & & $137.72 \pm 39.90$ & & $22 \pm 44.53$ & \\
\hline
\end{tabular}

${ }^{a}$ Mean \pm SD, n=5. BW: Body weight, HC: High-carbohydrate, HCEx: High-carbohydrate plus exercise, HCAs: High-carbohydrate plus ascorbic acid,

HCExAs: High-carbohydrate plus exercise

Table 2: Result of paired samples t-test on body weight before and after treatment in each group

\begin{tabular}{llll}
\hline Group & \multicolumn{2}{l}{ Body weight $(\mathrm{g})$} & p value \\
\cline { 2 - 3 } & Before $^{\mathrm{a}}$ & After $^{\mathrm{a}}$ & \\
\hline HC & $128.60 \pm 7.44$ & $176.83 \pm 17.72$ & 0.003 \\
HCEx & $130.40 \pm 11.01$ & $151.93 \pm 22.30$ & 0.136 \\
HCAs & $114.00 \pm 15.70$ & $165.71 \pm 9.67$ & 0.007 \\
HCExAs & $115.60 \pm 10.81$ & $137.72 \pm 39.90$ & 0.329 \\
\hline
\end{tabular}

${ }^{a}$ Mean \pm SD, $n=5$. BW: Body weight, HC: High-carbohydrate,

HCEx: High-carbohydrate plus exercise, HCAs: High-carbohydrate plus ascorbic acid, HCExAs: High-carbohydrate plus exercise

it might decrease insulin sensitivity that leads to the lack of glucose uptake by cells [6]. The dose of ascorbic acid in this research was in moderate dose, so it needs further exploration. The group which carried out the regular exercise had lower BG level. Based on similar studies, it was because of the role of reguler exercise to regulate BG level as its energy source for exercise and the improvement of muscle GLUT4 (glucose transpoter-4) expression that lead to an uptake more of blood glucose by cells [13]. Vasudevan and Hirsch [14] and Sharma et al. [15] also found the BG elevation due to intravenous ascorbic acid. Yet, the other study by Dakhale et al. [16] stated that ascorbic acid consumption reduced the $B G$ level in diabetic patients.

The balance of antioxidant and free radicals is important to establish the normal body function. Based on several studies, free radicals induced insulin secretion $[17,18]$. When insulin secretion increase, blood glucose uptake also increase by the cells, then BG level become lower than before. On the other hand, a study revealed that exercise also stimulated free radicals production. Besides that, it has been known that because of contraction (i.e., exercise), there is an increase of calsium ion in muscle cells that can generate free radicals (H2O2), and in sequence reactions, they induce GLUT4 translocation and cause glucose uptake by cells [19]. However, ascorbic acid addition reduced the effect of free radicals, subsequently, insulin secretion and glucose uptake decrease, and the reduction of BG will lessen compared to the group without ascorbic acid.

\section{Islets of the pancreas}

The largest area of pancreatic islets (islets per square micrometer) was $\mathrm{HC}$ group, subsequently HCAs group, and HCEx group, and the smallest was HCExAs group. Nevertheless, as shown in Fig. 4, it did not show significantly different among groups ( $\mathrm{p}=0.065)$.

The difference of the hematoxylin-eosin staining of pancreatic islets is exemplified in Fig. 5. for each group.

The largest area of pancreatic islets was HC diet group, without any additional exercise nor ascorbic acid. Yet, it demonstrated no significant difference among the groups. This result was in line with Adeyi et al. [7] which stated no difference among groups on pancreatic islets due to high glycemic index diet on rats. Other research which assessed the distinction of insulin level on sedentary and exercise training persons, and it informed that insulin serum level in exercise training group was lower compared to the sedentary. However, insulin content in pancreatic islets did not exhibit dissimilarity [20]. Nevertheless, contradiction result was published by Sheng et al. [21], and it unveiled beta cell mass expansion in high glucose diet for 12 weeks compared to control group. Virtually, this study also discovered bigger pancreatic islets area but insignificantly difference.

The bigger pancreatic islets in HC diet may be a compensation mechanism to protect the body from hyperglycemia. The larger pancreatic islets area produced more insulin leading to increase glucose uptake. In accordance with our result which the greatest pancreatic islets area in HC diet group, which also had a normal level of BG. In case, lengthy duration of treatment and then persistence of hyperglycemia, in series response, it would stimulate abundance free radical production, which triggers apoptosis [22].

\section{CONCLUSION}

Regular exercise controlled BG level on HC rats. It could be the involvement of increasing GLUT4 translocation. Ascorbic acid appeared to slow down glucose uptake, so BG level was higher compared to the 
Table 3: The average of BG: Before (BG pre), after (BG post), and the difference (BG diff) during the treatment

\begin{tabular}{|c|c|c|c|c|c|c|}
\hline Groups & BG pre $(\mathrm{mg} / \mathrm{dL})^{\mathrm{a}}$ & p value & BG post $(\mathrm{mg} / \mathrm{dL})^{\mathrm{a}}$ & p value & BG diff $(\mathrm{mg} / \mathrm{dL})^{\mathrm{a}}$ & p value \\
\hline $\mathrm{HC}$ & $134 \pm 10.43$ & 0.122 & $150 \pm 19.18$ & 0.169 & $16 \pm 22.90$ & 0.009 \\
\hline HCEx & $137 \pm 13.06$ & & $134 \pm 13.90$ & & $-3 \pm 2.41^{\circ \times \Delta}$ & \\
\hline HCAs & $120 \pm 10.37$ & & $151 \pm 7.09$ & & $31 \pm 13.56$ & \\
\hline HCExAs & $142 \pm 19.83$ & & $142 \pm 9.00$ & & $1 \pm 14.12^{\circ \times \Delta}$ & \\
\hline
\end{tabular}

a Mean \pm SD, n=5. BW: Body weight, HC: High-carbohydrate, HCEx: High-carbohydrate plus exercise, HCAs: High-carbohydrate plus ascorbic acid,

HCExAs: High-carbohydrate plus exercise

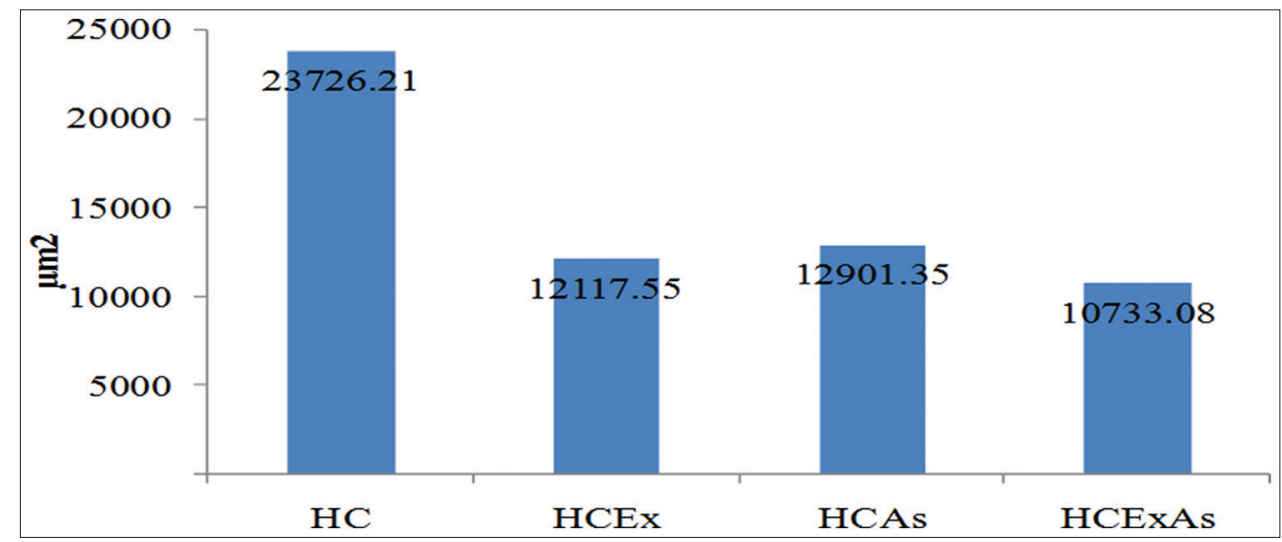

Fig. 4: Islets pancreatic area in each group. No significantly different among groups $(p=0.065)$

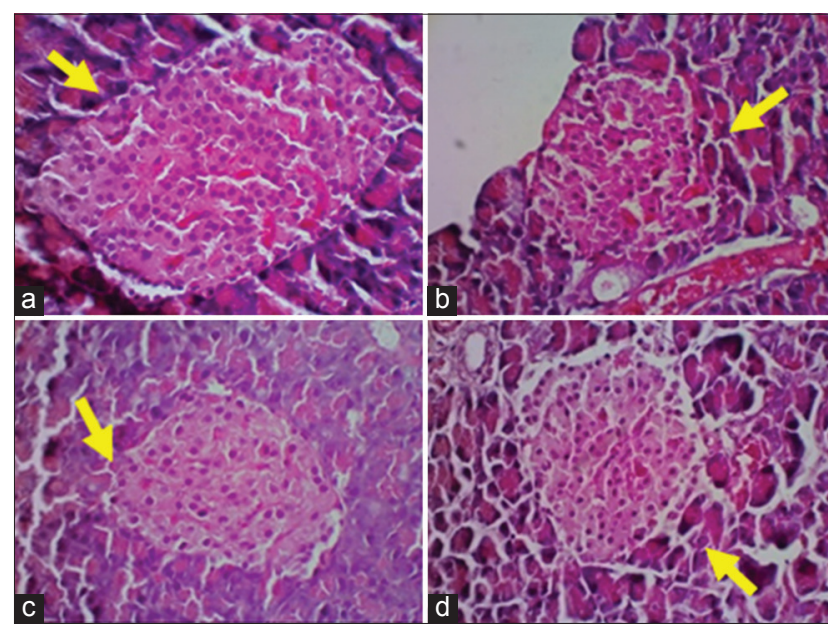

Fig. 5: The area of islets of the pancreas (arrow) with hematoxylin-eosin staining. Microscope Nikon eclipse Ci, enlarged 400×, Optilab Viewer 2.2, Image raster 3.0.

(a) high-carbohydrate (HC), (b) HC plus exercise, (c) HC plus ascorbic acid, HCEx and ascorbic acid

exercise group on HC rats. The combination of exercise and ascorbic acid seemed to have better effect on weight and BG. Yet, both exercise and ascorbic acid or their combined effect did not differ islet pancreatic area. Based on existing evidence, exercise and ascorbic acid combination may have a benefit effect for HC diet subject. However, further research needs to explore the certain mechanism such as insulin sensitivity, insulin receptor, GLUT, apoptosis, level of free radicals, and antioxidants.

\section{CONFLICTS OF INTEREST}

All authors have none to declare.

\section{ACKNOWLEDGMENT}

The authors thank Dr. Wahyu Wibowo, MSi (Institute Teknologi Sepuluh November, Surabaya), for his statistical analysis and the Faculty of
Medicine, Universitas Airlangga, for supporting the grants from the Minister of Higher Education of Indonesia.

\section{REFERENCES}

1. Basu S, Yoffe P, Hills N, Lustig RH. The relationship of sugar to population-level diabetes prevalence: An econometric analysis of repeated cross-sectional data. PLoS One 2013;8:e57873.

2. Guariguata L, Whiting DR, Hambleton I, Beagley J, Linnenkamp U, Shaw JE, et al. Global estimates of diabetes prevalence for 2013 and projections for 2035. Diabetes Res Clin Pract 2014;103:137-49.

3. Benkar AP, Kanase SB. Effect of aerobic exercises and resistance training on glucose levels in Type 2 diabetic subjects. Asian J Pharm Clin Res 2017;10:360.

4. Anděl $M$, Němcová $V$, Pavlíková $N$, Urbanová J, Cecháková $M$, Havlová A, et al. Factors causing damage and destruction of beta-cells of the islets of Langerhans in the pancreas. Vnitr Lek 2014;60:684-90.

5. Zhao LG, Shu XO, Li HL, Zhang W, Gao J, Sun JW, et al. Dietary antioxidant vitamins intake and mortality: A report from two cohort studies of chinese adults in Shanghai. J Epidemiol 2017;27:89-97.

6. Herawati L, Anshori N, Harjanto H. Peningkatan performa atlet selam dengan pemberian antioksidan. J Iptek Olahraga 2012;14:258-267.

7. Adeyi AO, Idowu BA, Mafiana CF, Oluwalana SA, Ajayi OL, Akinloye OA, et al. Rat model of food-induced non-obese-Type 2 diabetes mellitus: Comparative pathophysiology and histopathology. Int J Physiol Pathophysiol Pharmacol 2012;4:51-8.

8. Kusumawati D. Bersahabat Dengan Hewan Coba. $1^{\text {st }}$ ed. Yogyakarta: UGM Press-Badan Penerbit dan Publikasi Universitas Gadjah Mada; 2004.

9. Kanter M. High-quality carbohydrates and physical performance: Expert panel report. Nutr Today 2018;53:35-9.

10. Ferreira GA, Felippe LC, Silva RL, Bertuzzi R, De Oliveira FR, Pires FO, et al. Effect of pre-exercise carbohydrate availability on fat oxidation and energy expenditure after a high-intensity exercise. Braz J Med Biol Res 2018;51:e6964.

11. Colberg SR, Sigal RJ, Yardley JE, Riddell MC, Dunstan DW, Dempsey PC, et al. Physical activity/exercise and diabetes: A position statement of the American diabetes association. Diabetes Care 2016;39:2065-79.

12. Lee D, Hwang W, Artan M, Jeong DE, Lee SJ. Effects of nutritional components on aging. Aging Cell 2015;14:8-16.

13. Herawati L, Irwadi I, Sari GM, Harjanto. Peningkatan Protein Pengangkut Gula (Glut4) Dengan Diet Tinggi Karbohidrat dan Latihan Fisik Teratur. Proceeding Kongres Nas. IAIFI XVI, Simp. Seminar Nasional, dan Work. XXIV Interak. Padang: Holistik antara Org. dan 
Lingkung. untuk Kualitas Hidup yang Lebih Baik Ketahanan Pangan, Kesehatan, dan Prestasi Olahraga; 2015. p. 796-806.

14. Vasudevan S, Hirsch IB. Interference of intravenous Vitamin C with blood glucose testing. Diabetes Care 2014;37:e93-4.

15. Sharma E, Resta C, Park P. A case of factitious hyperglycemia in a patient on intravenous ascorbic acid. Case Rep Endocrinol 2018;2018:7063137.

16. Dakhale GN, Chaudhari HV, Shrivastava M. Supplementation of Vitamin $\mathrm{C}$ reduces blood glucose and improves glycosylated hemoglobin in Type 2 diabetes mellitus: A randomized, double-blind study. Adv Pharmacol Sci 2011;2011:195271.

17. Leloup C, Tourrel-Cuzin C, Magnan C, Karaca M, Castel J, Carneiro L, et al. Mitochondrial reactive oxygen species are obligatory signals for glucose-induced insulin secretion. Diabetes 2009;58:673-81.

18. McConell GK, Kingwell BA. Does nitric oxide regulate skeletal muscle glucose uptake during exercise? Exerc Sport Sci Rev 2006;34:36-41.

19. Katz A. Modulation of glucose transport in skeletal muscle by reactive oxygen species. J Appl Physiol (1985) 2007;102:1671-6.

20. Almeida FN, Proença AR, Chimin P, Marçal AC, Bessa-Lima F, Carvalho CR, et al. Physical exercise and pancreatic islets: Acute and chronic actions on insulin secretion. Islets 2012;4:296-301.

21. Sheng Q, Xiao X, Prasadan K, Chen C, Ming Y, Fusco J, et al. Autophagy protects pancreatic beta cell mass and function in the setting of a high-fat and high-glucose diet. Sci Rep 2017;7:16348.

22. Campos C. Chronic hyperglycemia and glucose toxicity: Pathology and clinical sequelae. Postgrad Med 2012;124:90-7. 